\title{
Tsimshian Language
}

National Cancer Institute

\section{Source}

National Cancer Institute. Tsimshian Language. NCI Thesaurus. Code C154175.

A dialect of the Tsimshian language spoken in northwestern British Columbia and southeastern Alaska. 